\title{
Polyacrylate Decorating Poly(ethylene terephthalate) (PET) Film Surface for Boosting Oxygen Barrier Property
}

\author{
Wen Zhong ${ }^{1}$, Xiaobin Yang ${ }^{1, *}$, Jikun Sun ${ }^{1}$, Hongwei Gao ${ }^{1}$, Yongping Bai ${ }^{1,2, *}$ and Lu Shao ${ }^{1,3, *(D)}$ \\ 1 School of Chemistry and Chemical Engineering, Harbin Institute of Technology, Harbin 150001, China; \\ zhongw20032003@163.com (W.Z.); sjk289947216@gmail.com (J.S.); gaohongwei18@163.com (H.G.) \\ 2 Wuxi HIT New Material Research Institute Co., Ltd., Wuxi 214100, China \\ 3 Key Laboratory of Materials Processing and Mold, Ministry of Education, National Engineering Research \\ Center for Advanced Polymer Processing Technology, Department of Chemical Engineering, Zhengzhou \\ University, Zhengzhou 450002, China \\ * Correspondence: xiaobin.yang@hit.edu.cn (X.Y.); baifengbai@hit.edu.cn (Y.B.); shaolu@hit.edu.cn (L.S.)
}

\section{check for} updates

Citation: Zhong, W.; Yang, X.; Sun, J.; Gao, H.; Bai, Y.; Shao, L. Polyacrylate Decorating Poly(ethylene terephthalate) (PET) Film Surface for Boosting Oxygen Barrier Property. Coatings 2021, 11, 1451. https:// doi.org/10.3390/coatings11121451

Received: 26 October 2021

Accepted: 24 November 2021

Published: 26 November 2021

Publisher's Note: MDPI stays neutral with regard to jurisdictional claims in published maps and institutional affiliations.

Copyright: (c) 2021 by the authors. Licensee MDPI, Basel, Switzerland. This article is an open access article distributed under the terms and conditions of the Creative Commons Attribution (CC BY) license (https:// creativecommons.org/licenses/by/ $4.0 /)$.

\begin{abstract}
Polymeric barrier materials are critical in contemporary industries for food, medicine, and chemical packaging. However, these materials, such as PET films, are impeded by the optimization of barrier properties by virtue of molecular design. Herein, a new methyl methacrylate-methyl acrylate-diallyl maleate-maleic acid (MMA-MAc-DAM-MA) was synthesized to tailor the surface properties of PET films for maximizing oxygen barrier properties. During the MMA-MAc-DAM-MA coating and curing process, the chemical structure evolutions of MMA-MAc-DAM-MA coatings were characterized, indicating that the cross-linking conversion and proportion of - $\mathrm{COOH}$ groups are critical for the oxygen barrier properties of coatings. The inherent $-\mathrm{COOH}$ groups are transformed into designed structures, including intramolecular anhydride, inter-chain anhydride and retained carboxylic acid. Therein, the inter-chain anhydride restraining the activity of coated polymer chain mainly contributes to enhanced barrier properties. The thermal properties of novel coatings were analyzed, revealing that the curing behavior is strongly dependent on the curing temperatures. The impacts of viscosity of the coating solution, coating velocity, and coating thickness on the oxygen permeability $\left(\mathrm{PO}_{2}\right)$ of the coatings were investigated using a gas permeability tester to explore the optimum operating parameters during practical applications, which can reduce the $\mathrm{PO}_{2}$ of PET film by $47.8 \%$. This work provides new insights on advanced coating materials for excellent barrier performance.
\end{abstract}

Keywords: film; barrier property; surface modification; cross-linking; gas transport

\section{Introduction}

High-barrier packaging materials are capable of inhibiting the penetration of osmotic molecules such as oxygen, water vapor, and carbon dioxide, and they have been extensively applied to prolong the shelf life of food [1,2], cigarettes, medicine, and chemicals [3-6]. The solution-diffusion model is a classic model used to describe the penetration of osmotic molecules through barrier materials. It divides the penetration into three steps: (1) the osmotic molecules dissolve into the membrane by the contact surface, (2) the osmotic molecules diffuse in the membrane under a concentration gradient, and (3) the osmotic molecules desorb at the other side of the membrane [7-9]. The second step is the principal process that affects the transfer process $[10,11]$. There are two models to explain diffusion [12-14]. One is the free volume model, which holds that the increased activity of chains brings about new conformation to arouse the expansion of free volume, which would provide more free space for the movements of permeating molecules [15-18], thus facilitating the diffusion process [19]. The second model is based on the percolation theory, which suggests that improving the activity of polymer chains is critical to creating channels for the osmotic molecules' transmission [20], which can greatly shorten the time of 
diffusion [21-23]. So, it is convincing that reducing the activity of molecular chains is the decisive method to block diffusion [24-26].

PET film as a packaging material does not fully fulfill the requirement of the oxygen barrier property $[27,28]$. Polymeric coating, which is characterized by a simple operation, low cost [29,30], diverse functionality [31,32], and benign adhesion [33], is promising for the functionalization of PET film. Currently, two types of polymer coatings have been mainly studied to promote the barrier capability of PET films: crystalline polymers and amorphous polymers [34,35]. The former includes polyvinyl alcohol (PVA) [36] and polyvinylidene chloride (PVDC) [37]. The other one is an amorphous polymer coating with a cross-linking structure and entangled network [38]. However, the development of crystalline polymers is impeded by several shortcomings during practical applications. For example, PVA with rich hydroxyl groups brings out two problems: One is that high-density hydroxyl groups easily form hydrogen bonds [39], resulting in the low solid content but high viscosity of the solution [40] and huge difficulty in the coating operation. The other is that the coating is moisture absorption-sensitive, easily resulting in the serious deterioration of the oxygen barrier property [41] and peeling strength [42]. For PVDC, the surface tension of emulsion is larger than PET film, causing surface cratering in the coating process to reduce the barrier property [43-45]. Moreover, both the weak adhesion of PVDC coating with PET substrate [46-48] and the brittleness of the coating deteriorate the barrier property [49-51]. However, solvent-based amorphous polymers with a high oxygen barrier property [52-54] are promising solutions for avoiding these problems [55-57].

Herein, an amorphous polyacrylate was synthesized by methyl methacrylate (MMA)methyl acrylate (MAc)-diallyl maleate (DAM)-maleic acid (MA) in the coating process, and the oxygen barrier properties of as-prepared composite PET films were investigated. We characterized and analyzed the cross-linking structure and density of MMA-Mac-DAM-MA at different curing temperatures and their influences on the oxygen barrier properties of PET films. The influence of the viscosity of the coating solution on the surface morphology of the coating, coating velocity, and coating thickness were also investigated to optimize their oxygen barrier performances.

\section{Experimental}

\subsection{Material}

Methyl methacrylate (MMA), methyl acrylate (MAc), diallyl maleate (DAM), maleic acid (MA), benzoyl peroxide (BPO), and N-methylpyrrolidone (NMP) are all analytical reagents and were purchased from Aladdin (Shanghai, China). These chemicals were used without further purification.

\subsection{Polymer Synthesis}

MMA (50 g), Mac (12 g), DAM (0.5 g), MA (15 g), and NMP (55 g) were mixed with $\mathrm{BPO}(0.21 \mathrm{~g})$ in the four-necked flask. The temperature was raised to $88^{\circ} \mathrm{C}$. The mixture was stirred for $2 \mathrm{~h}$. Then, the temperature was increased to $90^{\circ} \mathrm{C}$, and the mixture of NMP $(130 \mathrm{~g})$ and $\mathrm{BPO}(0.14 \mathrm{~g})$ was dripped into the solution. The dripping time was controlled for $4 \mathrm{~h}$. Finally, the temperature was raised to $94{ }^{\circ} \mathrm{C}$ and maintained for $4 \mathrm{~h}$. After that, the solution was cooled to room temperature.

\subsection{Preparation of Oxygen Barrier Coatings}

Vacuum distillation was employed to remove solvent from the synthetic polymer. The solvent-free polymer was ground into powder. Then, the powder was extracted thrice with deionized water at $50{ }^{\circ} \mathrm{C}$ to remove the residual monomer of MA. Additionally, the purified powder was filtered by vacuum distillation again to eliminate water. Then, the anhydrous powder was dissolved in NMP to compose a polymer solution with specific viscosity. The polymer solution was coated with a specified thickness on PET film $(210 \mathrm{~mm} \times 297 \mathrm{~mm} \times 15 \mu \mathrm{m})$ with a small coater (type PT-5000PL, Baoda, Dongguan, China) at designated coating speed. The coating rod was 16 inches long and available 
in 4 diameters. Finally, the coated PET films were stored at the assigned temperature of $130-210{ }^{\circ} \mathrm{C}$ in an air circulation oven (DHG-9140 A, Yiheng, Shanghai, China).

\subsection{Characterization}

\subsubsection{Morphology of Coatings}

The substrate and coated PET films were all tested by F20 thin-film analyzer (Filmetrics, San Diego, CA, USA) to measure their average thickness. The surface morphology of the coating was investigated by BX51 polarization microscope (Olympus, Tokyo, Japan) using the light transmission method with the magnification of 100 times.

\subsubsection{Oxygen Permeability of Coating}

The oxygen permeability $\left(\mathrm{PO}_{2}\right)$ of the coated PET films was determined by OX-TRAN Model 702 Gas Permeability Tester (Mocon, Minneapolis, MN, USA) at $80 \%$ RH and $23{ }^{\circ} \mathrm{C}$. The thickness of the PET substrate was about $12 \mu \mathrm{m}, 15 \mu \mathrm{m}, 25 \mu \mathrm{m}$, and the thickness of the coating was related to specified requirements.

\subsubsection{Structure of the Coating}

The coatings were separated from the coated PET film. Additionally, the coating samples were analyzed by Nicolet IS5 Fourier Transform Infrared Spectroscopy (FT-IR) (ThermoFisher, Waltham, MA, USA). The spectral resolution was $4 \mathrm{~cm}^{-1}$. The scans were 32 times. Additionally, the range was from 600 to $3600 \mathrm{~cm}^{-1}$.

\subsubsection{Curing Mechanism Analysis}

The coatings were separated from the coated PET film. The thermal performances of the coatings were detected by DSC200F3 Differential Scanning Calorimetry (DSC) (NET$\mathrm{ZSCH}$, Selb, Germany) at a heating rate of $5{ }^{\circ} \mathrm{C} / \mathrm{min}$ under nitrogen atmosphere. The test interval was from 10 to $220^{\circ} \mathrm{C}$.

\subsubsection{Thermogravimetric Analysis}

The coatings were separated from the coated PET film. The coating samples were measured by TG209F3 Thermogravimetric analysis (NETZSCH, Selb, Germany). The test interval was from 10 to $450^{\circ} \mathrm{C}$ under nitrogen atmosphere with a heating rate of $10^{\circ} \mathrm{C} / \mathrm{min}$.

\section{Results and Discussion}

\subsection{Synthesis and Characterization of MMA-MAc-DAM-MA Copolymer}

The MMA-MAc-DAM-MA copolymer was synthesized from MMA, MAc, DAM, and MA. The schematic diagram of synthesizing process is shown in Figure 1, and the structure was studied by FT-IR, as shown in Figure 2.

As for the results of FT-IR spectra, the stretching bands at 1149 and $1193 \mathrm{~cm}^{-1}$ correspond to the stretch vibration of $-\mathrm{C}-\mathrm{O}-\mathrm{C}-$ groups. The peak at $1448 \mathrm{~cm}^{-1}$ refers to $-\mathrm{CH}_{3}$ groups, and the $1730 \mathrm{~cm}^{-1}$ peak is attributed to $\mathrm{C}=\mathrm{O}$ groups. The characteristic peak of the $-\mathrm{OH}$ bond rose at $3338 \mathrm{~cm}^{-1}$ in the MMA-MAc-DAM-MA coating, owing to the $-\mathrm{COOH}$ groups. In the spectrum of the copolymer, the bands of the vinylic bond at 1640 (from MMA and MA) and $1647 \mathrm{~cm}^{-1}$ (from DAM) all disappeared, which reveals that MMA, MAc, DAM and MA reacted. 


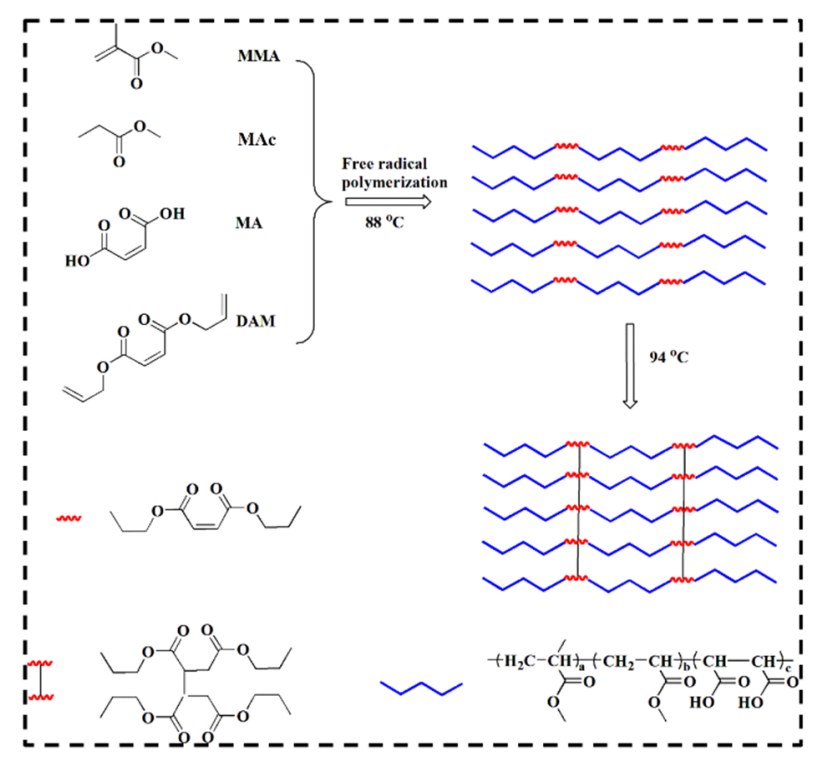

Figure 1. Schematic diagram of MMA-MAc-DAM-MA copolymer synthesized process.

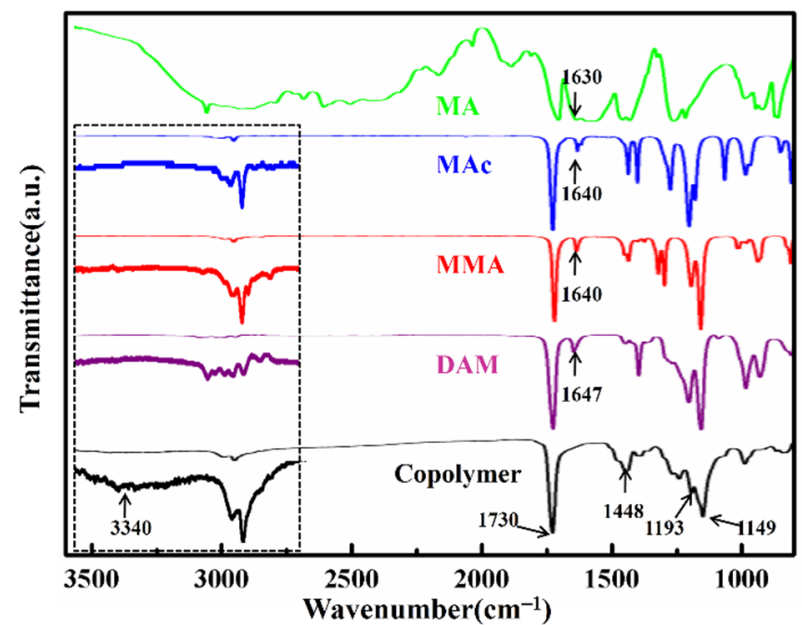

Figure 2. FTIR spectra of monomers (MA, MMA, Mac, and DAM), compared with the copolymer (MMA-MAc-DAM-MA).

\subsection{Effect of Curing Temperature on the Barrier Performance of Coated PET Film}

The polymer coating of MMA-MAc-DAM-MA contains a considerable number of carboxyl groups $(-\mathrm{COOH})$, which can form inter-chain crosslinking during the curing process. This is critical for improving the oxygen barrier performance of coating because the enhanced cross-linking degree could restrict the movement of the copolymer chains. As for coating, the formation of the cross-linking structure requires heating. So, curing temperature was the most significant parameter influencing the oxygen barrier property of the coated PET films in the coating process. First, we prepared the coated PET films with a consistent thickness of $19 \mu \mathrm{m}(15 \mu \mathrm{m}$ substrate and $4 \mu \mathrm{m}$ coating) and dried them at specific temperatures for exactly $40 \mathrm{~s}$ each. Afterward, the $\mathrm{PO}_{2}$ of the coated PET films was investigated (Figure 3). 


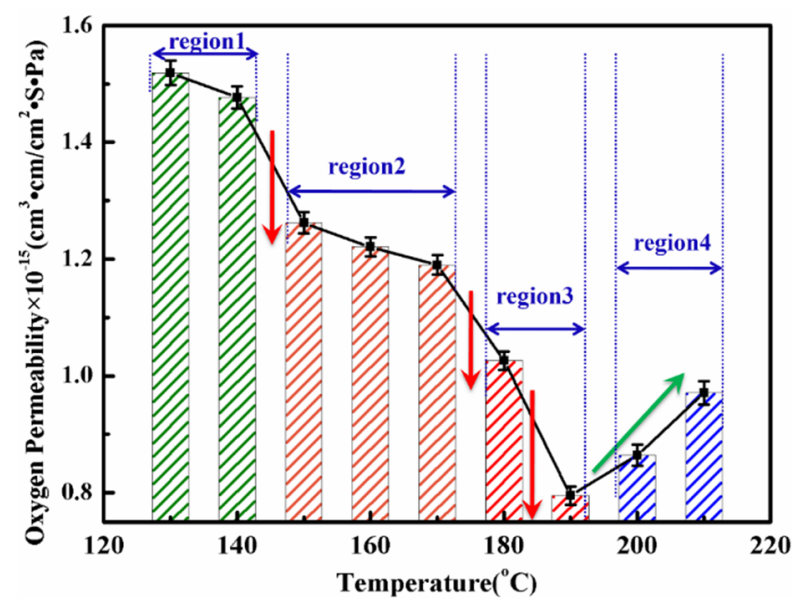

Figure 3. $\mathrm{PO}_{2}$ of coated PET film cured at different temperatures.

The $\mathrm{PO}_{2}$ of the coated PET film at different curing temperatures was divided into four regions. The first is $130-140{ }^{\circ} \mathrm{C}$ (region 1 ). The coating cured at these two temperatures did not improve the oxygen barrier property of the PET films. The second region is 150-170 ${ }^{\circ} \mathrm{C}$ (region 2). When the curing temperature was $150{ }^{\circ} \mathrm{C}$, the $\mathrm{Po}_{2}$ of the coated PET film decreased dramatically by $14.3 \%$. This is evidence that the barrier performance improved. However, when the curing temperature was set at 160 and $170{ }^{\circ} \mathrm{C}$, the $P_{\mathrm{O}_{2}}$ of the coated films just slightly decreased by $1.7 \%$ and $3.8 \%$, respectively, similarly to the coating cured at $150{ }^{\circ} \mathrm{C}$. So, the coatings cured at the region 2 temperatures were all able to block oxygen, but their barrier capacities were similar to each other. The third region is the curing temperature at $180-190{ }^{\circ} \mathrm{C}$ (region 3). When the curing temperature was $180{ }^{\circ} \mathrm{C}$, the barrier performance of the coating improved significantly again. The $\mathrm{PO}_{2}$ of the coated film decreased by $14.4 \%$ compared to that cured at $170{ }^{\circ} \mathrm{C}$. When the curing temperature was $190^{\circ} \mathrm{C}$, the $\mathrm{Po}_{2}$ of the coated film decreased by $22.6 \%$, further contrasting with the coated film cured at $180{ }^{\circ} \mathrm{C}$. Additionally, it was the minimum record of coated PET films at any curing temperature. So, the coatings cured at region 3 can better improve the oxygen barrier of the PET film. The fourth region is the treatment temperature of 200-210 ${ }^{\circ} \mathrm{C}$ (region 4). The $\mathrm{Po}_{2}$ of the coated PET films cured at region 4 were 0.864 and $0.971 \times 10^{-15} \mathrm{~cm}^{3} \cdot \mathrm{cm} /\left(\mathrm{cm}^{2} \cdot \mathrm{s} \cdot \mathrm{Pa}\right)$, respectively, both greater than the $\mathrm{Po}_{2}$ of the coated PET films cured at $190{ }^{\circ} \mathrm{C}\left(0.795 \times 10^{-15} \mathrm{~cm}^{3} \cdot \mathrm{cm} /\left(\mathrm{cm}^{2} \cdot \mathrm{s} \cdot \mathrm{Pa}\right)\right)$, indicating their barrier performances degraded.

\subsection{Analysis of Cross-Linking Structure of Curing Coating}

The oxygen barrier property of the coating is dominated by the structure and activity of the coated polymer chains. So, we applied FT-IR to analyze the structure of the coating dried at specific temperatures. The results are shown in Figure 4a.

When the coating was cured at 130 and $140{ }^{\circ} \mathrm{C}, 1630 \mathrm{~cm}^{-1}$ was the $\mathrm{C}=\mathrm{O}$ stretching of $-\mathrm{COOH}$, as shown in Figure $4 \mathrm{~b}$. The stretching peak was absent at $1776 \mathrm{~cm}^{-1}$ and $1832 \mathrm{~cm}^{-1}$, as shown in Figure 4c,d, respectively. This indicates that the structures of anhydride (-CO-O-O-C-) do not exist in these coatings. So, the $-\mathrm{COOH}$ groups remained without cross-linking. The schematic of the presumed coating polymer chain structures at 130 and $140{ }^{\circ} \mathrm{C}$ is shown in Figure 5a. Similarly, the structure analyses of the as-prepared coating at other curing temperatures are also proposed in Figure 5. 

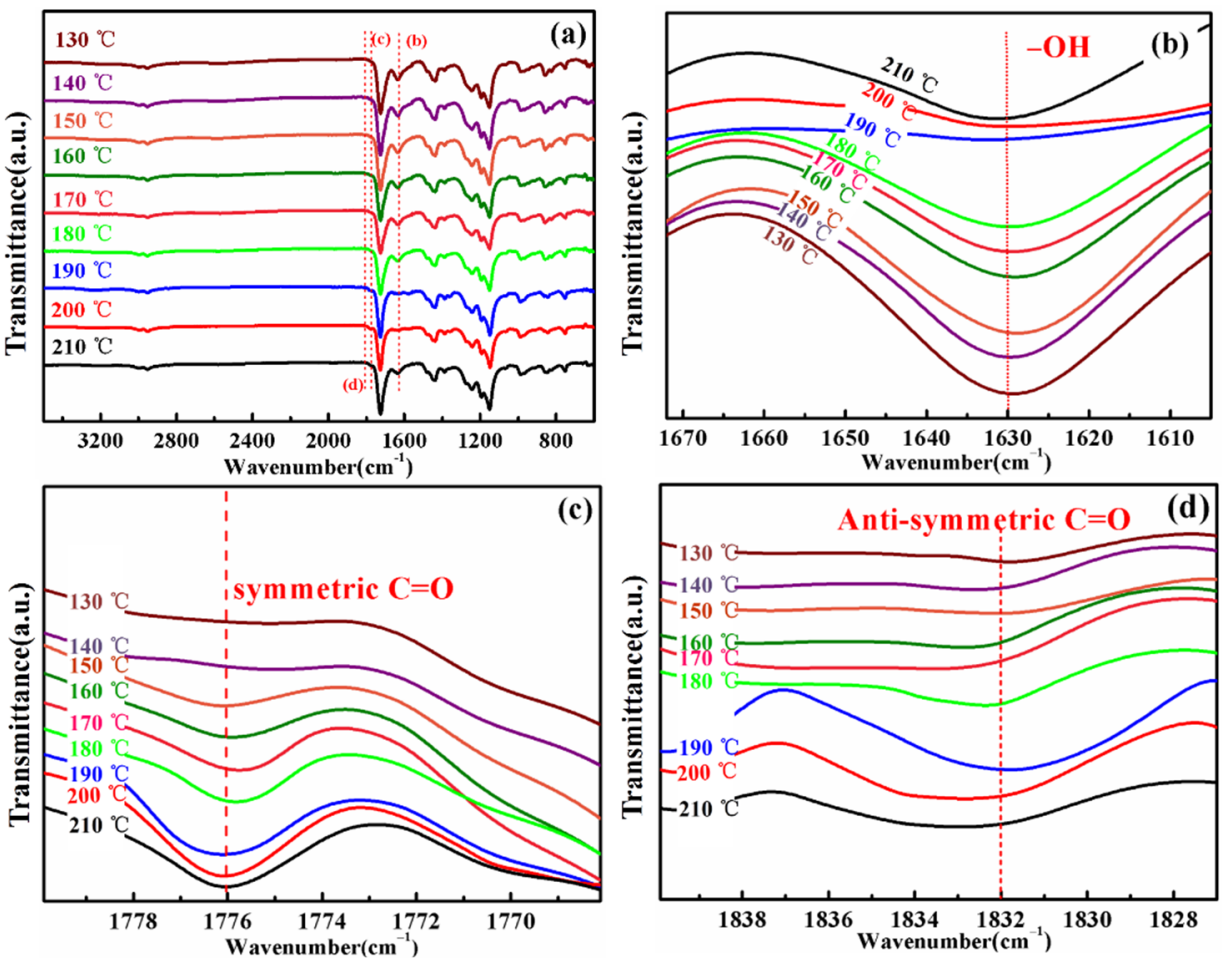

Figure 4. FTIR spectra of the coatings cured at different temperatures in the range of (a) $3600-600 \mathrm{~cm}^{-1}$, (b) $1670-1610 \mathrm{~cm}^{-1}$, (c) $1780-1768 \mathrm{~cm}^{-1}$, and (d) $1840-1827 \mathrm{~cm}^{-1}$.

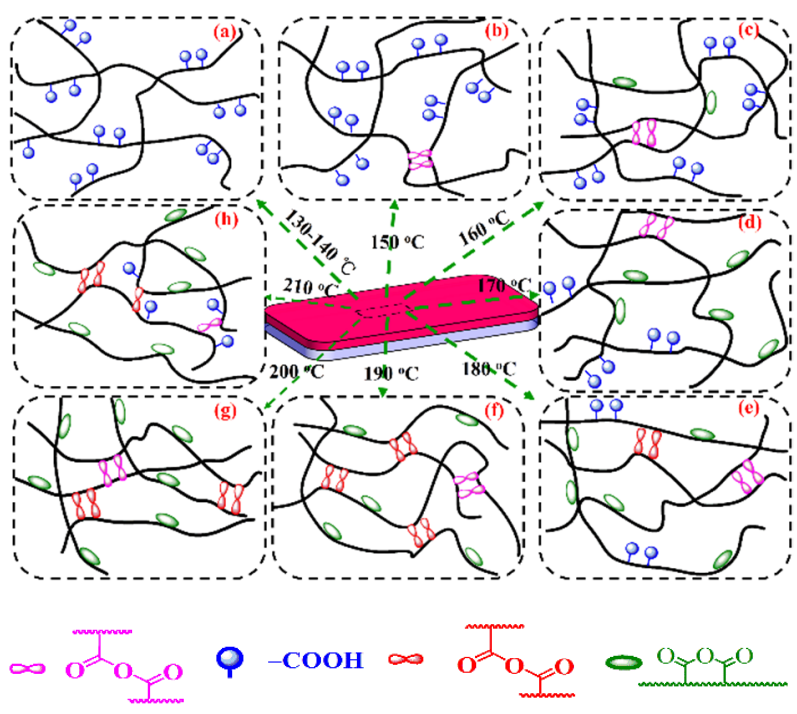

$-\mathrm{COOH}$ goups with narrow space $-\mathrm{COOII}$ goups with narrow space

Figure 5. The structure of coating cured at different temperatures: (a) coating cured at 130 and $140{ }^{\circ} \mathrm{C}$; (b) coating cured at $150{ }^{\circ} \mathrm{C} ;(\mathbf{c})$ coating cured at $160^{\circ} \mathrm{C},(\mathbf{d})$ coating cured at $170{ }^{\circ} \mathrm{C} ;(\mathbf{e})$ coating cured at $180{ }^{\circ} \mathrm{C} ;(\mathbf{f})$ coating cured at $190{ }^{\circ} \mathrm{C} ;(\mathrm{g})$ coating cured at $200{ }^{\circ} \mathrm{C} ;(\mathbf{h})$ coating cured at $210{ }^{\circ} \mathrm{C}$.

For the coating cured at $150{ }^{\circ} \mathrm{C}$, a stretching peak is displayed at $1776 \mathrm{~cm}^{-1}$ which is related to the symmetric $-\mathrm{C}=\mathrm{O}$ of $-\mathrm{CO}-\mathrm{O}-\mathrm{O}-\mathrm{C}-$, as shown in Figure $4 \mathrm{c}$. This indicates a few $-\mathrm{COOH}$ groups were converted to anhydride structures. Combining with the result as shown in Figure 3, the barrier performance of the coating improved dramatically when the treatment temperature of $150{ }^{\circ} \mathrm{C}$ replaced $140{ }^{\circ} \mathrm{C}$. This illustrated that these anhydride structures can effectively limit the movement of the chain. So, it is possibly the cross-chain anhydride created by dehydration. Additionally, we assume this cross-linking is formed 
by the $-\mathrm{COOH}$ groups, whose chain spaces are narrower than intramolecular carboxylic acid spacing (Figure 5b).

For the coating cured at $160{ }^{\circ} \mathrm{C}$, the intensity of the $1630 \mathrm{~cm}^{-1}$ peak, as shown in Figure $4 \mathrm{~b}$, is weaker than that of the coating cured at $150^{\circ} \mathrm{C}$. The intensity of the $1776 \mathrm{~cm}^{-1}$ stretching peak is greater than that of the coating cured at $150^{\circ} \mathrm{C}$, as shown in Figure $4 \mathrm{c}$. This illustrates that more $-\mathrm{COOH}$ groups are turning to $-\mathrm{CO}-\mathrm{O}-\mathrm{O}-\mathrm{C}-$ groups. However, the diminution of $-\mathrm{COOH}$ groups fails to bring evident improvement of barrier performance, as shown in Figure 3. So, this indicates that the vanished - $\mathrm{COOH}$ groups tend to convert to the structure that has a very weak restriction on the movement of the chain. This is most likely intramolecular anhydride, which is useless for improving the oxygen barrier ability of coating.

For the coating cured at $170{ }^{\circ} \mathrm{C}$, the intensity of $1630 \mathrm{~cm}^{-1}$ peak weakened again compared with that of the coating cured at $160{ }^{\circ} \mathrm{C}$, as shown in Figure $4 \mathrm{~b}$, while the intensity of the $1776 \mathrm{~cm}^{-1}$ stretching peak strengthened, as shown in Figure 4c. However, the improvement of the barrier performance is still poor. Similar to the coating cured at $160{ }^{\circ} \mathrm{C}$, the $-\mathrm{COOH}$ groups also convert to intramolecular anhydrides. The schematic of the presumed coating polymer chain structures at $170{ }^{\circ} \mathrm{C}$ is shown in Figure $5 \mathrm{~d}$. We found that at the higher temperatures of 160 and $170{ }^{\circ} \mathrm{C}$, the $-\mathrm{COOH}$ groups tend to transform into intramolecular anhydrides instead of inter-chain cross-linking anhydrides. So, we speculate that the $-\mathrm{COOH}$ groups that transformed into inter-chain cross-linking anhydride at the lower temperature of $150^{\circ} \mathrm{C}$ possess a narrower chain space than intramolecular ones.

For the coating cured at $180{ }^{\circ} \mathrm{C}$, the intensity of the $1630 \mathrm{~cm}^{-1}$ stretching peak decreased, as shown in Figure $4 \mathrm{~b}$, while the intensity of the $1776 \mathrm{~cm}^{-1}$ peak strengthened, as shown in Figure 4c. It can be observed that the stretching peak of reverse symmetric $-\mathrm{C}=\mathrm{O}$ of $-\mathrm{CO}-\mathrm{O}-\mathrm{O}-\mathrm{C}-$ emerged at $1832 \mathrm{~cm}^{-1}$. More anhydride structures were formed. With the $\mathrm{PO}_{2}$ of the coated PET film cured at $180^{\circ} \mathrm{C}$ decreasing again, a part of $-\mathrm{COOH}$ groups may have converted to inter-chain anhydrides. Additionally, this may be distinctive of the interchain cross-linking anhydrides formed at $150{ }^{\circ} \mathrm{C}$. The chain spaces of cross-linking $-\mathrm{COOH}$ groups at this temperature are probably more than intramolecular spaces. The schematic of the presumed coating polymer chain structures at $180^{\circ} \mathrm{C}$ is shown in Figure 5e.

For the coating cured at $190{ }^{\circ} \mathrm{C}$, the $1630 \mathrm{~cm}^{-1}$ peak was eliminated, as shown in Figure $4 \mathrm{~b}$. It was demonstrated that the $-\mathrm{COOH}$ groups of the coating were consumed completely (Figure 5f). The intensity of the stretching peak at $1776 \mathrm{~cm}^{-1}$ kept growing, as shown in Figure 4c. Additionally, the intensity of the stretching peaks at $1832 \mathrm{~cm}^{-1}$ was the strongest of all the coatings, as shown in Figure $4 \mathrm{~d}$. Since the $\mathrm{P}_{\mathrm{O}_{2}}$ of the coated PET film was the lowest, as shown in Figure 3, the coating may be characterized by the maximum proportion of inter-chain anhydrides.

For the coating cured at $200{ }^{\circ} \mathrm{C}$, the peak at $1630 \mathrm{~cm}^{-1}$ was eliminated, as shown in Figure $4 \mathrm{~b}$. However, the intensity of the stretching peak at $1834 \mathrm{~cm}^{-1}$ was weaker than that of the coating cured at $190{ }^{\circ} \mathrm{C}$, as shown in Figure $4 \mathrm{~d}$. At this curing temperature, the curing speed is excessive, so the molecular chain movement is restricted prematurely to form large network cross-linking structure, which results in the decrease in the proportion of cross-linking carboxylic acid. The - $\mathrm{COOH}$ groups that were too late to participate in the inter-chain cross-linking reaction transformed into intramolecular anhydrides or remained as they were. That is why the $\mathrm{Po}_{2}$ of the coated PET film treated at $200{ }^{\circ} \mathrm{C}$ rebounds, as shown in Figure 3. The schematic of the presumed coating of the polymer chain structures at $200{ }^{\circ} \mathrm{C}$ is shown in Figure $5 \mathrm{~g}$.

For the coating cured at $210{ }^{\circ} \mathrm{C}$, the $1630 \mathrm{~cm}^{-1}$ peak appeared again, as shown in Figure $4 \mathrm{~b}$. The intensity of the stretching peaks at 1776 and $1832 \mathrm{~cm}^{-1}$ were all weaker than that of coatings cured at 190 or $200^{\circ} \mathrm{C}$. This curing temperature exceeds the boiling point of NMP $\left(203^{\circ} \mathrm{C}\right)$. Therefore, the solvent volatilizes quickly, arousing the rapid curing of the coating. This leads to the incomplete rearrangement of molecular segments and finally results in $-\mathrm{COOH}$ residue. Thus, the $\mathrm{PO}_{2}$ of the coated PET film treated at $210{ }^{\circ} \mathrm{C}$ 
exceeded those at 190 and $200{ }^{\circ} \mathrm{C}$, as shown in Figure 3. The schematic of the presumed coating polymer chain structures at $210^{\circ} \mathrm{C}$ is shown in Figure $5 \mathrm{~h}$.

\subsection{DSC Analysis of Coatings Cured at Different Temperatures}

The DSC of the curing coatings is shown in Figure 6. All coatings cured at different temperatures showed two endothermic intervals. The first is the glass transition of the coating (from 30 to $95^{\circ} \mathrm{C}$ ). The second is the temperature interval of the residual $-\mathrm{COOH}$ that corresponds to the transformation of anhydride by dehydration in the heating process.

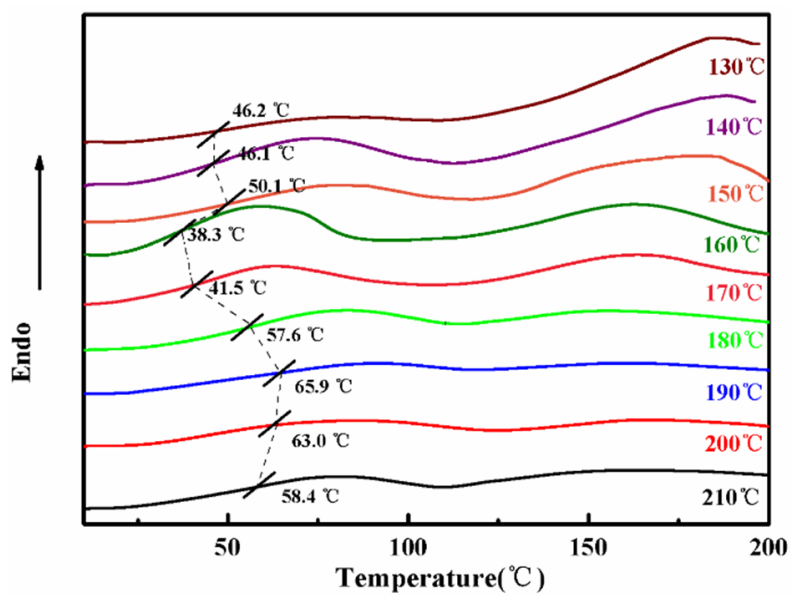

Figure 6. DSC spectra of coatings cured at different temperatures.

However, the two intervals' characteristics vary for coatings cured at different temperatures as follows: (1) the glass transition temperatures $(\mathrm{Tg})$ of the coating cured at 130 and $140{ }^{\circ} \mathrm{C}$ were 46.2 and $46.1{ }^{\circ} \mathrm{C}$, respectively. Additionally, the area of the second endothermic peak was larger than that of coatings cured at other temperatures. This indicates that the coating cured at these two temperatures contains abundant $-\mathrm{COOH}$ groups without reacting. (2) the second endothermic peak of the coating cured at $150{ }^{\circ} \mathrm{C}$ decreases, which indicates that the content of $-\mathrm{COOH}$ in coating reduced, while the $\mathrm{Tg}$ rose to $50.1^{\circ} \mathrm{C}$, which demonstrates the diminished - $\mathrm{COOH}$ groups converting to the structure that could restrict the motion of chain. (3) The Tg of the coating cured at 160 and $170{ }^{\circ} \mathrm{C}$ were 38.3 and $41.5^{\circ} \mathrm{C}$, respectively, which are below that of the coating curried at $150^{\circ} \mathrm{C}$. However, the area of the second endothermic peak decreased significantly. This indicates, again, that the diminished $-\mathrm{COOH}$ groups were converted to intramolecular anhydride, because, with the consumption of $-\mathrm{COOH}$, the proportion of acid anhydride in the molecule increased gradually, but the proportion of hydrogen bonds decreased. Restricting the motion of the polymer chain had a negative effect. So, the Tg values of coatings descended. (4) The $\mathrm{Tg}$ of the coating cured at $180^{\circ} \mathrm{C}$ was $57.6^{\circ} \mathrm{C}$, and the area of the second endothermic peak decreased further. From the analysis of FT-IR, it is known that the new cross-chain anhydrides that strengthen the restricting of chain motion are formed at this treatment temperature. So, the Tg and oxygen barrier properties all rose again. (5) The $\mathrm{Tg}$ of the coating cured at $190^{\circ} \mathrm{C}$ was $65.9^{\circ} \mathrm{C}$, which was the highest of all the coatings. The chains with the lowest mobility can be attributed to the maximum proportion of inter-chain cross-linking. (6) The $\mathrm{Tg}$ of the coating cured at $200^{\circ} \mathrm{C}$ was $63.0^{\circ} \mathrm{C}$, which was less than that of the coating cured at $190^{\circ} \mathrm{C}$. However, the area of the second endothermic peak was similar to that of the coating cured at $190^{\circ} \mathrm{C}$. It corresponds exactly with the precondition that when most of the- $\mathrm{COOH}$ groups are depleted, the coating cured at $200{ }^{\circ} \mathrm{C}$ becomes less proportionate in the cross-linking structures between chains, and the oxygen barrier performance is also inferior to that of the coating cured at $190{ }^{\circ} \mathrm{C}$. (7) The Tg of the coating at $210^{\circ} \mathrm{C}$ descended to $58.4^{\circ} \mathrm{C}$. The area of the second endothermic peak was enlarged compared with that of the coating cured at $190{ }^{\circ} \mathrm{C}$. This is attributed to the remaining - $\mathrm{COOH}$ groups from the rapid curing. The remained $-\mathrm{COOH}$ groups resulted in the decreasing numbers of 
cross-linking structures and releasing the mobility of partial molecular chains. So, the $\mathrm{Tg}$ and oxygen barrier performance of the coating both descended. The DSC results are consistent with the $\mathrm{PO}_{2}$ test data in Figure 3 and the structure analysis conclusions about Figure 4 . So, the oxygen barrier performance relates to the cross-linking structure and density, which are determined by the curing temperature in the coating process.

\subsection{The Effect of Coating Thicknesson Oxygen Barrier Property of Coated Film}

It is well known that the permeability of dense polymeric films decreases with their increasing thickness. For coated PET films, the effect of thickness on coated film permeability can be expressed as follows in parallel-type Equations (1) and (2):

$$
\begin{gathered}
\frac{d}{p}=\frac{d_{c}}{p_{c}}+\frac{d_{s}}{p_{s}} \\
d=d_{c}+d_{s}
\end{gathered}
$$

where $d$ is the thickness of the coated film, $p$ is the permeability of the coated film, $d_{c}$ is the thickness of the coating, $p_{c}$ is the permeability of the coating, $d_{s}$ is the thickness of substrate, and $p_{S}$ is the permeability of the substrate. Combine Equations (1) and (2) to Equation (3) to achieve:

$$
\frac{d_{c}+d_{s}}{p}=\frac{d_{c}}{p_{c}}+\frac{d_{s}}{p_{s}}
$$

where $d_{s}, p_{s}$ and $p_{c}$ are fixed, as set $\frac{d_{s}}{p_{s}}$ as constant $c_{0}, d_{s}$ as constant $c_{1}$, set $p_{c}$ as constant $c_{2}$. The Equation (3) is converted to Equations (4)-(8):

$$
\begin{gathered}
\frac{d_{c}+c_{1}}{p}=\frac{d_{c}}{c_{2}}+c_{0} \\
\frac{d_{c} c_{2}+c_{1} c_{2}}{p}=d_{c}+c_{0} c_{2} \\
p=\frac{d_{c} c_{2}+c_{1} c_{2}}{d_{c}+c_{0} c_{2}} \\
p=\frac{d_{c} c_{2}+c_{0} c_{2} c_{2}-c_{0} c_{2} c_{2}+c_{1} c_{2}}{d_{c}+c_{0} c_{2}} \\
p=c_{2}+\frac{c_{1} c_{2}-c_{0} c_{2} c_{2}}{d_{c}+c_{0} c_{2}}
\end{gathered}
$$

Set $c_{1} c_{2}-c_{0} c_{2} c_{2}$ as constant $c_{3}, c_{0} c_{2}$ as constant $c_{4}$.

The Equation (8) is converted to Equation (9):

$$
p=c_{2}+\frac{c_{3}}{d_{c}+c_{4}}
$$

The increasing $d_{c}$ makes the $p$ decrease. So, increasing the thickness of the coating is one of the easiest ways to improve the barrier properties of the coating film. But we found that the results are inconsistent with expectations in practical applications. The relationship between coating thickness and coating film is shown in Figure 7a. 


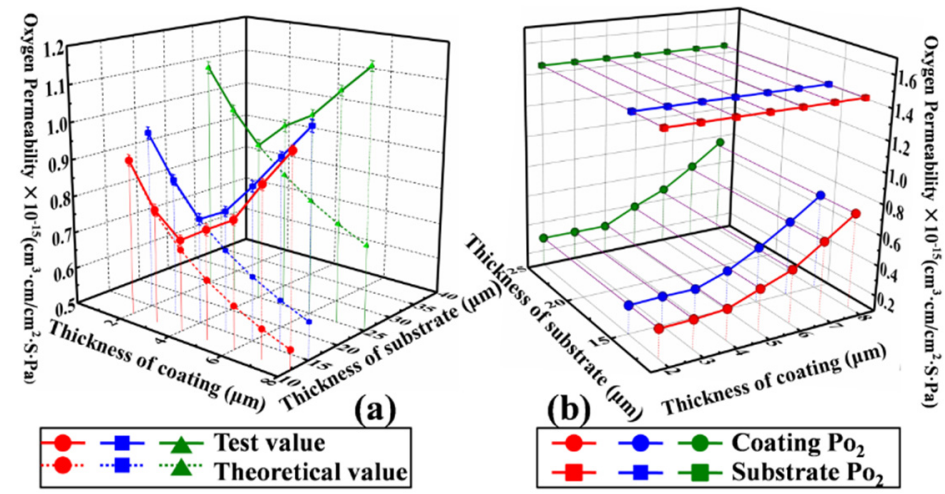

Figure 7. The effect of coating thickness on the oxygen barrier property: (a) theoretical and test $\mathrm{PO}_{2}$ of PET films coated by with different thicknesses; (b) $\mathrm{P}_{2}$ of substrate, coatings with different MMA-MAc-DAM-MA coating thicknesses.

According to theoretical calculations, the $\mathrm{P}_{2}$ variation of the coated film with increasing thickness should be present as the dash in Figure 8a. However, the test values deviated from the theory. To verify the universality of this result, we selected three PET substrates with different thicknesses for testing. The conclusion is unanimous. Whatever the thickness of the PET substrate is, whether it is 12,15 or $25 \mu \mathrm{m}$, the $\mathrm{PO}_{2}$ of coated PET films is decreased in accordance with the theoretical calculation up to a coating thickness over $4 \mu \mathrm{m}$. However, when the coating thickness reaches $5 \mu \mathrm{m}$, the test $P_{\mathrm{O}_{2}}$ of the coating film deviates from the theoretical value. Additionally, with increasing thickness, the deviation becomes larger and larger. However, the $\mathrm{PO}_{2}$ of the substrate is constant, and the discrepancy is bound to coating. By using Equation (1), we calculated the $P_{\mathrm{o}_{2}}$ of the coating at various thicknesses, as shown Figure $7 \mathrm{~b}$.
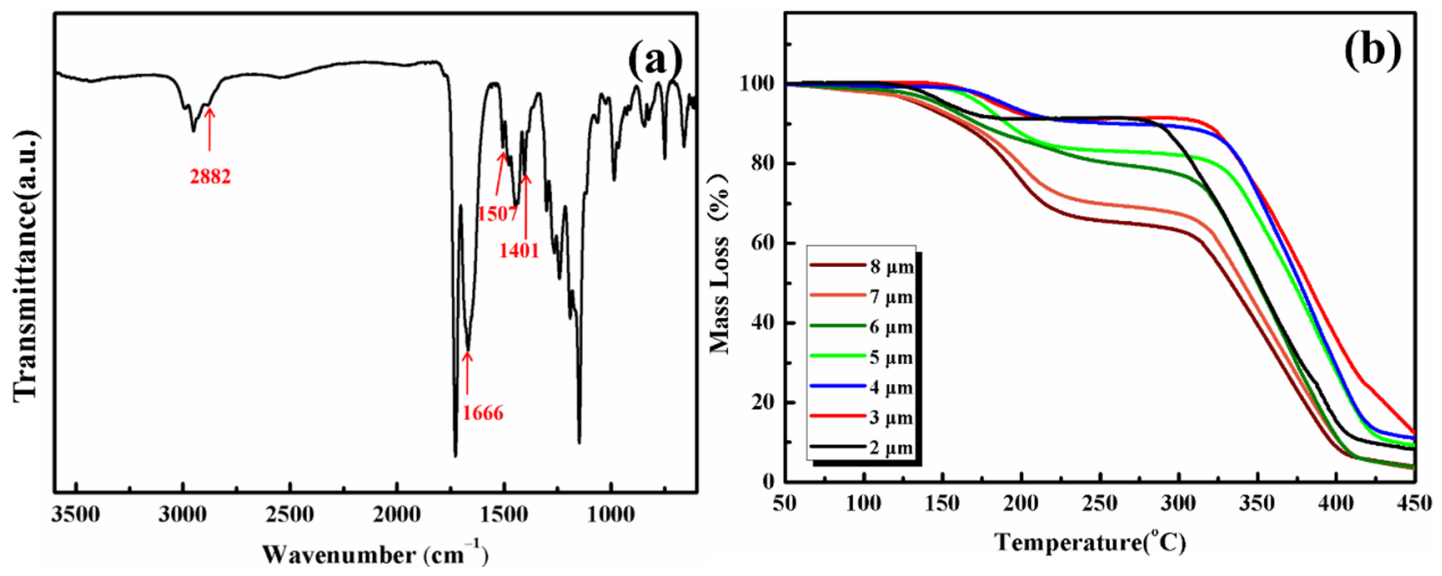

Figure 8. (a) FTIR analysis of the MMA-MAc-DAM-MA coating thicker than $4 \mu \mathrm{m},(\mathbf{b})$ thermogravimetric analysis of the MMA-MAc-DAM-MA coating with different thicknesses.

We found that when the thickness of the coating exceeded $4 \mu \mathrm{m}$, the $\mathrm{P}_{2}$ of the coating begins to increase. This reveals that the coating thickness should not be as thick as possible. The effect of the coating with a thickness above $4 \mu \mathrm{m}$ on improving the barrier property was gradually weakened due to the efficiency decline in its own oxygen barrier. In addition, we found that regardless of the substrate thickness, the $\mathrm{PO}_{2}$ of the coating at the same thickness is almost the same in comparison. This is not an accident. The same problem exists in these coatings and worsens with increasing thickness. We performed an infrared analysis for coatings thicker than $4 \mu \mathrm{m}$. We found that the new stretching bands of 2882, 1666, 1507, and $1401 \mathrm{~cm}^{-1}$ emerged, as shown in Figure 8a. They do not belong to the structure of MMA-MAc-DAM-MA copolymer but perfectly fit the characteristics of NMP. 
The NMP remained in the coating with greater thickness. Thermogravimetric analysis was applied to test the coating with different thicknesses. The results are shown in Figure $8 \mathrm{~b}$.

The thermo stability of a coating with a thickness between 2 and $4 \mu \mathrm{m}$ is nearly the same in the temperature range of $200-300{ }^{\circ} \mathrm{C}$. However, the thermo stability of the coating decreases with raising thickness between 5 and $8 \mu \mathrm{m}$ in the temperature range of $200-300{ }^{\circ} \mathrm{C}$. The principal reason for this is that the increased thickness of a coating makes volatilization of the solvent in the coating greatly difficult. So, it can be considered that $4 \mu \mathrm{m}$ is the critical thickness of MMA-MAc-DAM-MA coating. This difficulty is easily eliminated by multiple thin layers of coating. Moreover, excessive curing temperature or curing time easily causes film wrinkling, which results in breaking the oxygen barrier property of PET-coated film. Additionally, the residual solvent supplies activity for molecular chains, resulting in the $\mathrm{PO}_{2}$ increase in the coating. Meanwhile, the thick coating easily forms an uneven surface, which greatly burdens coating speed, solution viscosity, and the self-leveling property of the coating. In summary, a $4 \mu \mathrm{m}$ thickness for coating can provide the most efficient barrier property and is suitable for industrial applications.

\subsection{The Effect of Coating Solution Viscosity and Coating Speed on Barrier Property of Coated PET} Film

According to our theoretical calculations, the $\mathrm{Po}_{2}$ value of the $19 \mu \mathrm{m}$ coated film (15 $\mu \mathrm{m}$ substrate and $4 \mu \mathrm{m}$ coating) should be $0.782 \times 10^{-15} \mathrm{~cm}^{3} \cdot \mathrm{cm} /\left(\mathrm{cm}^{2} \cdot \mathrm{s} \cdot \mathrm{Pa}\right)$. So, we collected many data at different coating speeds and copolymer solution viscosities in practical applications to find this key point in realizing the theoretical value. The results are shown in Figure 9. It can be observed that a high viscosity copolymer solution (1400-1600 cps) with a low coating speed ( $5 \mathrm{~m} / \mathrm{min}$ ) easily forms conspicuous protrusions on the coating surface, as seen in Figure 9a. If the coating speed is slow, the insufficient shear force causes the accumulation of shifted coating on the basement membrane, and the coating with high viscosity needs a long time to spread the accumulation to form a flat surface. The protrusions, which are harmful to barrier properties, are generated easily at low speed with a high viscosity copolymer solution. So, the $\mathrm{PO}_{2}$ of these coated films are over $1.45 \times 10^{-15} \mathrm{~cm}^{3} \cdot \mathrm{cm} /\left(\mathrm{cm}^{2} \cdot \mathrm{s} \cdot \mathrm{Pa}\right)$. On the contrary, low viscosity copolymer solutions (100-200 cps) with a fast coating speed $(50 \mathrm{~m} / \mathrm{min})$ cause defects in the coating, as shown in Figure $9 \mathrm{~b}$. If the coating speed is fast while the solution viscosity is low, the air at the interface will likely remain. The residual air converts into bubbles, which break to form defects during the heating process. These defects are fatally destructive to the oxygen barrier property of the coating. In fact, the worst $\mathrm{PO}_{2}$ of these coated films are $1.83 \times 10^{-15} \mathrm{~cm}^{3} \cdot \mathrm{cm} /\left(\mathrm{cm}^{2} \cdot \mathrm{s} \cdot \mathrm{Pa}\right)$. The $P_{c}$ is 106 times the theoretical value. Eventually, a reasonable region of 400-600 cps copolymer solution viscosity and the ideal 15-25 m/min coating speed was found. In this range, the coating surface was smooth and flawless, as shown in Figure 9c. We tested the $\mathrm{PO}_{2}$ of the coated film with these parameters. The results are all below $0.830 \times 10^{-15} \mathrm{~cm}^{3} \cdot \mathrm{cm} /\left(\mathrm{cm}^{2} \cdot \mathrm{s} \cdot \mathrm{Pa}\right)$. At last, by trial and error, we confirmed the 600 cps copolymer solution viscosity and the $20 \mathrm{~m} / \mathrm{min}$ coating speed as the optimum parameters. The $\mathrm{PO}_{2}$ of the coated film at these two parameters was $0.786 \times 10^{-15} \mathrm{~cm}^{3} \cdot \mathrm{cm} /\left(\mathrm{cm}^{2} \cdot \mathrm{s} \cdot \mathrm{Pa}\right)$, infinitely close to the theoretical value of $0.782 \times 10^{-15} \mathrm{~cm}^{3} \cdot \mathrm{cm} /\left(\mathrm{cm}^{2} \cdot \mathrm{s} \cdot \mathrm{Pa}\right)$. 


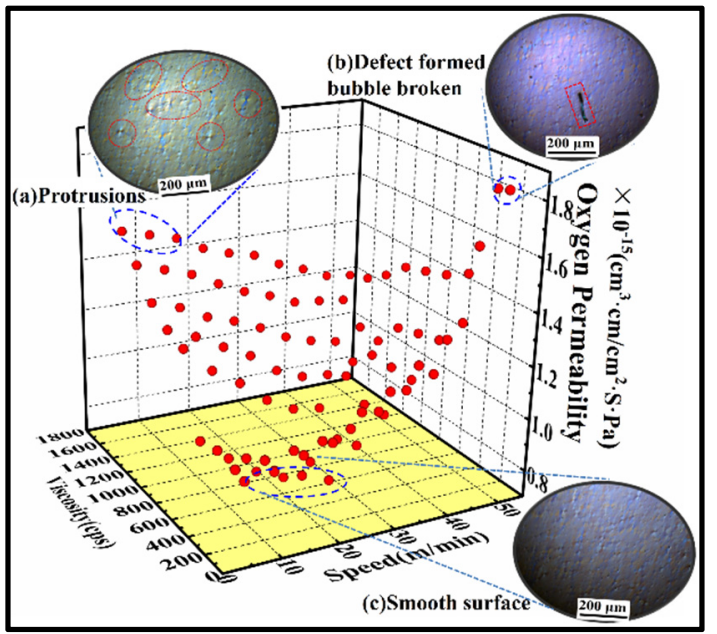

Figure 9. Effect of coating speed and copolymer solution viscosity on barrier properties of coated PET films. (a) Protrusions; (b) defect formed and bubble broken; (c) smooth surface.

\subsection{The Optimal Coating Process Parameters}

At the end of the experiment, we integrated the best obtained parameters to achieve an integral coating process. To verify the feasibility of this process, we prepared a $600 \mathrm{cps}$ copolymer solution and coated it at the speed of $20 \mathrm{~m} / \mathrm{min}$ with anRDS\#10 Mayerrod to ensure a coating $4 \mu \mathrm{m}$ thick after curing. At last, we dried the coated film in an oven at the temperature of $190{ }^{\circ} \mathrm{C}$. Then, we repeated this process ten times and tested the $\mathrm{PO}_{2}$ of each coated PET film. The results are reproducible at $0.786 \times 10^{-15} \mathrm{~cm}^{3} \cdot \mathrm{cm} /\left(\mathrm{cm}^{2} \cdot \mathrm{s} \cdot \mathrm{Pa}\right)$, as shown in Figure 10a. Consequently, as shown in Figure 10b, in practical application, it was confirmed that a $600 \mathrm{cps}$ copolymer solution viscosity, $20 \mathrm{~m} / \mathrm{min}$ coating speed, $4 \mu \mathrm{m}$ coating thickness, and $190{ }^{\circ} \mathrm{C}$ curing temperature achieve the best oxygen barrier effect for the coated film.

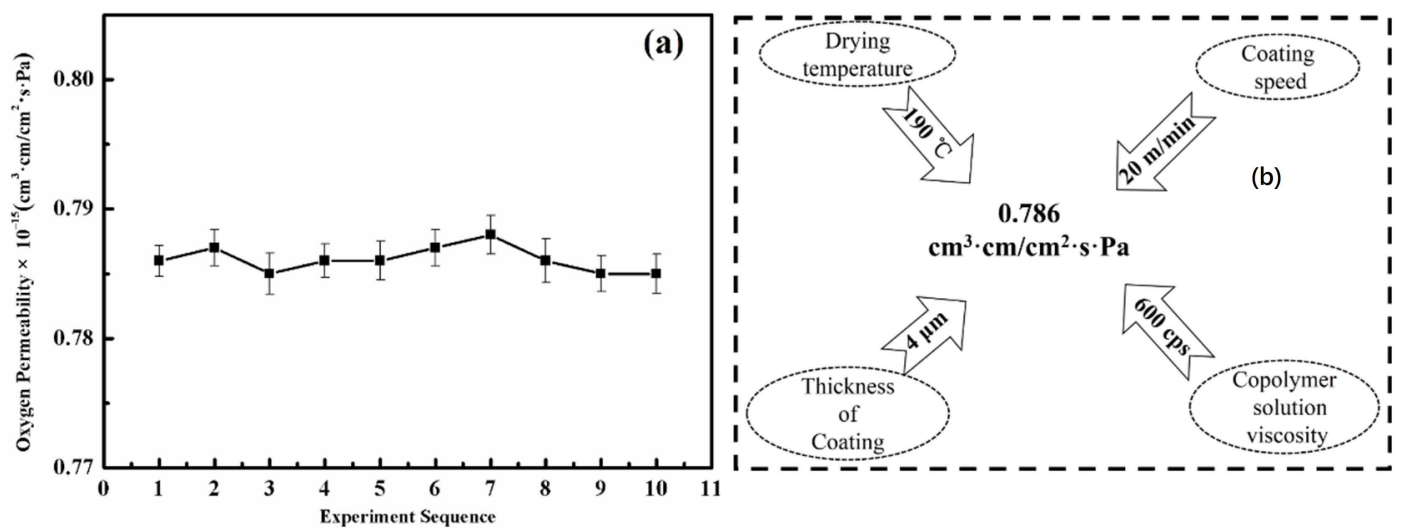

Figure 10. (a) $\mathrm{P}_{\mathrm{O}_{2}}$ of the coated film prepared at the optimal parameters, (b) key coating process parameters to obtain best barrier performance of coated film in practical application.

\section{Conclusions}

The synthesized copolymer of MMA-MAc-DAM-MA for coating can effectively improve the oxygen barrier property of the PET film. The curing temperature for coating is optimized at $190^{\circ} \mathrm{C}$. The coating cured at this temperature robustly enhanced the oxygen barrier performance for the coated PET film, maximizing inter-chain cross-linking and minimizing chain movement. The optimal coating thickness is $4 \mu \mathrm{m}$. This can provide the most efficient barrier property and is promising for practical industrial applications in food preservation and medicine storage. The results illustrate that the optimum solution 
viscosity range of copolymer is $400-600$ cps. In this interval, the coating process reaches the best leveling property and oxygen barrier coefficient. The appropriate coating speeds are $15-25 \mathrm{~m} / \mathrm{min}$, with an ideal speed of $20 \mathrm{~m} / \mathrm{min}$. At this speed, the coating surface is smooth and unblemished. Lastly and most importantly, a 600 cps copolymer solution viscosity, $20 \mathrm{~m} / \mathrm{min}$ coating speed, $4 \mu \mathrm{m}$ coating thickness, and $190{ }^{\circ} \mathrm{C}$ curing temperature are the optimal coating process parameters. They were combined to reduce the $\mathrm{PO}_{2}$ of the PET film (decrease by $47.8 \%$ ) in practical application. The MMA-MAc-DAM-MA coating provides new insights into the high oxygen barrier performance development of PET.

Author Contributions: Conceptualization, investigation, writing-original draft, W.Z.; funding acquisition, supervision, writing-review and editing, X.Y.; writing-review and editing, J.S. and H.G.; project administration, supervision, writing-review and editing, Y.B.; supervision, writingreview and editing, L.S. All authors have read and agreed to the published version of the manuscript.

Funding: X.Y. acknowledges the support from the China National Postdoctoral Program for Innovative Talents (Grant No. BX2021089).

Institutional Review Board Statement: Not applicable.

Informed Consent Statement: Not applicable.

Data Availability Statement: The data presented in this study are available on request from the corresponding authors.

Conflicts of Interest: The authors declare that they have no known competing financial interests or personal relationships that influenced the work reported in this paper.

\section{References}

1. Mchugh, T.H.; Avena-Bustillos, R.; Krochta, J.M. Hydrophilic edible films: Modifiedprocedure for water vapor permeability and explanation of thickness effects. J. Food Sci. 2010, 58, 899-903. [CrossRef]

2. Kandasamy, S.; Yoo, J.; Yun, J.; Kang, H.B.; Seol, K.H.; Kim, H.W.; Ham, J.S. Application of whey protein-based edible films and coatings in food industries: An updated overview. Coatings 2021, 11, 1056. [CrossRef]

3. Tenn, N.; Follain, N.; Fatyeyeva, K.; Poncin-Epaillard, F.; Labrugère, C.; Marais, S. Impact of hydrophobic plasma treatments on the barrier properties of poly(lactic acid) films. RSC Adv. 2014, 4, 5626. [CrossRef]

4. Yang, X.; Martinson, A.B.F.; Jeffrey, W.E.; Shao, L.; Darling, S.B. Water treatment based on atomically engineered materials: Atomic layer deposition and beyond. Matter 2021, 4, 3515-3548. [CrossRef]

5. Saito, A.; Obata, S.; Nishina, Y. Uniform coating of magnesium oxide crystal with reduced graphene oxide achieves moisture barrier performance. Appl. Surf. Sci. 2022, 573, 151483. [CrossRef]

6. Shi, Y.; Yuan, S.; Ter-Ovanessian, B.; Hermange, K.; Huo, Y.; Normand, B. Enhancing the barrier effect of sol-gel derived inorganic coating by doping h-BN nanosheet. Appl. Surf. Sci. 2021, 544, 148849. [CrossRef]

7. Lustig, S.R.; Peppas, N.A. Solute and penetrant diffusion in swellable polymers. VII. A free volume-based model with mechanical relaxation. J. Appl. Polym. Sci. 1987, 33, 533-549. [CrossRef]

8. Vieth, W.R.; Sladek, K.J. A model for diffusion in a glassy polymer. J. Colloid Sci. 1965, 20, 1014-1033. [CrossRef]

9. Müller-Plathe, F.; Rogers, S.C.; van Gunsteren, W.F. Gas sorption and transport in polyisobutylene: Equilibrium and nonequilibrium molecular dynamics simulations. J. Chem. Phys. 1993, 98, 9895-9904. [CrossRef]

10. Wang, J.; Pan, T.; Zhang, J.; Xu, X.; Yin, Q.; Han, J.; Wei, M. Hybrid films with excellent oxygen and water vapor barrier properties as efficient anticorrosive coatings. RSC Adv. 2018, 8, 21651-21657. [CrossRef]

11. Stergioudi, F.; Baxevani, A.; Mavropoulos, A.; Skordaris, G. Mechanical properties and diffusion barrier performance of CrWNcoatings fabricated through hybrid HiPIMS/RFMS. Coatings 2021, 11, 690. [CrossRef]

12. Zhou, S.-Y.; Chen, J.-B.; Li, X.-J.; Ji, X.; Zhong, G.-J.; Li, Z.-M. Innovative enhancement of gas barrier properties of biodegradable poly(butylene succinate) nanocomposite films by introducing confined crystals. RSC Adv. 2016, 6, 2530-2536. [CrossRef]

13. Scully, A.D.; Mao, Q.; Fell, C.J. High-performance oxygen barrier inorganic-organic coating for polymeric substrates. Surf. Coat. Technol. 2014, 239, 222-226. [CrossRef]

14. Haile, M.; Sarwar, O.; Henderson, R.; Smith, R.; Grunlan, J.C. Polyelectrolyte coacervates deposited as high gas barrier thin films. Macromol. Rapid Commun. 2017, 38, 1600594. [CrossRef]

15. Vrentas, J.S.; Duda, J.L. Diffusion in polymer-solvent systems. I. Reexamination of the free-volume theory. J. Polym. Sci. Pol. Phys. 1977, 15, 403-416. [CrossRef]

16. Heuchel, M.; Fritsch, D.; Budd, P.M.; McKeown, N.B.; Hofmann, D. Atomistic packing model and free volume distribution of a polymer with intrinsic microporosity (PIM-1). J. Membr. Sci. 2008, 318, 84-99. [CrossRef]

17. Takeuchi, H.; Roe, R.J.; Mark, J.E. Molecular dynamics simulation of diffusion of small molecules in polymers. II. Effect of free volume distribution. J. Chem. Phys. 1990, 93, 9042-9048. [CrossRef] 
18. Lau, C.H.; Li, P.; Li, F.; Chung, T.S.; Paul, D.R. Reverse-selective polymeric membranes for gas separations. Prog. Polym. Sci. 2013, 38, 740-766. [CrossRef]

19. Hagen, D.A.; Box, C.; Greenlee, S.; Xiang, F.; Regev, O.; Grunlan, J.C. High gas barrier imparted by similarly charged multilayers in nanobrick wall thin films. RSC Adv. 2014, 4, 18354-18359. [CrossRef]

20. Cheng, X.Q.; Konstas, K.; Doherty, C.M.; Wood, C.D.; Mulet, X.; Xie, Z.; Ng, D.; Hill, M.R.; Shao, L.; Lau, C.H. Hyper-cross-linked additives that impede aging and enhance permeability in thin polyacetylene films for organic solvent nanofiltration. ACS Appl. Mater. Interfaces 2017, 9, 14401-14408. [CrossRef] [PubMed]

21. Takeuchi, H. A jump motion of small molecules in glassy polymers: A molecular dynamics simulation. J. Chem. Phys. 1990, 93, 2062-2067. [CrossRef]

22. Hofmann, D.; Fritz, L.; Ulbrich, J.; Paul, D. Molecular simulation of small molecule diffusion and solution in dense amorphous polysiloxanes and polyimides. Comput. Theor. Polym. Sci. 2000, 10, 419-436. [CrossRef]

23. Müller-Plathe, F. Molecular dynamics simulation of gas transport in amorphous polypropylene. J. Chem. Phys. 1992, 96, 3200-3205. [CrossRef]

24. Lagaron, J.M.; Catalá, R.; Gavara, R. Structural characteristics defining high barrier properties in polymeric materials. Mater. Sci. Technol. 2013, 20, 1-7. [CrossRef]

25. Siepmann, J.; Gpferich, A. Mathematical modeling of bioerodible, polymeric drug delivery systems. Adv. Drug Deliv. Rev. 2001, 48, 229-247. [CrossRef]

26. Nakaya, M.; Yasuhara, S.; Maeda, T.; Hotta, A. Impact of hot wire and material gas species on the Cat-CVD coating of gas barrier SiOC thin films onto PET bottles. Surf. Coat. Technol. 2018, 344, 21-29. [CrossRef]

27. Angelo Miranda, M.; Jabarin, S.A.; Coleman, M. Modification of poly(ethylene terephthalate) (PET) using linoleic acid for oxygen barrier improvement: Impact of processing methods. J. Appl. Polym. Sci. 2017, 134, 45023. [CrossRef]

28. Wei, J.; Peng, S.; Xue, B.; Yang, Z.; Qin, S.; Yu, J.; Xu, G. Effect of silane functionalized graphene prepared by a supercritical carbon dioxide process on the barrier properties of polyethylene terephthalate composite films. RSC Adv. 2019, 9, 21903-21910. [CrossRef]

29. Chen, X.; Zhou, J.; Ma, J. Synthesis of a cationic fluorinated polyacrylate emulsifier-free emulsion via ab initio RAFT emulsion polymerization and its hydrophobic properties of coating films. RSC Adv. 2015, 5, 97231-97238. [CrossRef]

30. Azpitarte, I.; Botta, G.A.; Tollan, C.; Knez, M. SCIP: A new simultaneous vapor phase coating and infiltration process for tougher and UV-resistant polymer fibers. RSC Adv. 2020, 10, 15976-15982. [CrossRef]

31. Zhang, S.; Qiu, G.; Ting, Y.P.; Chung, T.S. Silver-PEGylated dendrimer nanocomposite coating for anti-fouling thin film composite membranes for water treatment. Colloids Surf. A 2013, 436, 207-214. [CrossRef]

32. Li, J.L.; Zhang, Y.; Zhang, S.; Liu, M.; Li, X.; Cai, T. Hyperbranchedpoly(ionic liquid) functionalized poly(ether sulfone) membranes as healable antifouling coatings for osmotic power generation. J. Mater. Chem. A 2019, 7, 8167-8176. [CrossRef]

33. Kornilova, N.; Bikbulatova, A.; Koksharov, S.; Aleeva, S.; Radchenko, O.; Nikiforova, E. Multifunctional polymer coatings of fusible interlinings for sewing products. Coatings 2021, 11, 616. [CrossRef]

34. Somorjai, G.A. Molecular level studies of solid-gas and solid-liquid interfaces. Surf. Sci. 1995, 335, 10-22. [CrossRef]

35. Idris, A.; Muntean, A.; Mesic, B.; Lestelius, M.; Javed, A. Oxygen barrier performance of poly(vinyl alcohol) coating films with different induced crystallin. Coatings 2021, 11, 1253. [CrossRef]

36. Liu, B.; Huang, X.; Wang, S.; Wang, D.; Guo, H. Performance of polyvinyl alcohol/bagasse fibre foamed composites as cushion packaging materials. Coatings 2021, 11, 1094. [CrossRef]

37. Amano, N.; Takahashi, M.; Uchiyama, H.; Kozuka, H. Transferability and adhesion of sol-gel-derived crystalline tio 2 thin films to different types of plastic substrates. Langmuir 2017, 33, 947-953. [CrossRef] [PubMed]

38. Yan, J.; Wang, X.; Chen, K.; Lee, K.N. Sintering modeling of thermal barrier coatings at elevated temperatures: A review of recent advances. Coatings 2021, 21, 1214. [CrossRef]

39. Dhieb, F.B.; Dil, E.J.; Tabatabaei, S.H.; Mighri, F.; Ajji, A. Effect of nanoclay orientation on oxygen barrier properties of LbL nanocomposite coated films. RSC Adv. 2019, 9, 1632-1641. [CrossRef]

40. Gupta, S.; Sindhu, S.; Varman, K.A.; Ramamurthy, P.C.; Madras, G. Hybrid nanocomposite films of polyvinyl alcohol and ZnO as interactive gas barrier layers for electronics device passivation. RSC Adv. 2012, 2, 11536. [CrossRef]

41. Huang, H.-D.; Ren, P.-G.; Chen, J.; Zhang, W.-Q.; Ji, X.; Li, Z.-M. High barrier graphene oxide nanosheet/poly(vinyl alcohol) nanocomposite films. J. Membr. Sci. 2012, 409-410, 156-163. [CrossRef]

42. Kim, J.M.; Lee, M.H.; Ko, J.A.; Kang, D.H.; Bae, H.; Park, H.J. Influence of food with high moisture content on oxygen barrier property of polyvinyl alcohol (PVA)/vermiculite nanocomposite coated multilayer packaging film. J. Food Sci. 2018, 83, 349-357. [CrossRef] [PubMed]

43. Brown, R.A.; Budd, P.M.; Price, C.; Satgurunathan, R. The permeability of poly(butyl acrylate)/poly(vinylidene chloride-statacrylonitrile) core/shell emulsion polymers for use as gas barrier coatings. Eur. Polym. J. 1993, 29, 337-342. [CrossRef]

44. Delafresnaye, L.; Dugas, P.Y.; Dufils, P.E.; Chaduc, I.; Vinas, J.M.; Lansalot, M.; Bourgeat-Lami, E. Synthesis of clay-armored poly(vinylidene chloride-co-methyl acrylate) latexes by Pickering emulsion polymerization and their film-forming properties. Polym. Chem. 2017, 8, 6217-6232. [CrossRef] 
45. Gamier, J.; Dufils, P.E.; Vinas, J.; Vanderveken, Y.; Herk, A.V.; Lacroix-Desmazes, P. Synthesis of poly(vinylidene chloride)-based composite latexes by emulsion polymerization from epoxy functional seeds for improved thermal stability. Polym. Degrad. Stab. 2012, 97, 170-177. [CrossRef]

46. Hwang, T.; Pu, L.; Kim, S.W.; Oh, Y.S.; Nam, J.D. Synthesis and barrier properties of poly(vinylidene chloride-coacrylonitrile)/ $\mathrm{SiO} 2$ hybrid composites by sol-gel process. J. Membr. Sci. 2016, 345, 90-96. [CrossRef]

47. Kodani, T.; Sakai, H.; Okabe, T.; Nomura, M. Effect of vinylidene chloride content on film-formation property of vinylidene chloride-methyl acrylate copolymer latex. J. Appl. Polym. Sci. 2015, 69, 565-572. [CrossRef]

48. Collins, S.; Yoda, K.; Anazawa, N.; Birkinshaw, C. Thermal stability of some vinylidene chloride copolymers. Polym. Degrad. Stab. 1999, 66, 87-94. [CrossRef]

49. Wu, M.S.; Painter, P.C.; Coleman, M.M. Further studies of the preferred chain conformation of crystalline poly(vinylidene chloride). J. Polym. Sci. Pol. Phys. Ed. 1980, 18, 95-110. [CrossRef]

50. Yu, Z.; Jia, H.; Li, B.; Li, B. Mechanism and kinetics of emulsion copolymerization of vinylidene chloride-Critical conversion at the end of interval 2 and rate of polymerization. Polym. Int. 2010, 30, 441-444. [CrossRef]

51. Velasquez, E.; Rieger, J.; Stoffelbach, F.; d'Agosto, F.; Lansalot, M.; Dufils, P.E.; Vinas, J. Surfactant-free poly(vinylidene chloride) latexes via one-pot RAFT-mediated aqueous polymerization. Polymer 2016, 106, 275-284. [CrossRef]

52. Benaniba, M.T.; Belhaneche-Bensemra, N.; Gelbard, G. Stabilizing effect of epoxidized sunflower oil on the thermal degradation of poly(vinyl chloride). Polym. Degrad. Stab. 2001, 74, 501-505. [CrossRef]

53. Wang, C.; Mo, B.; He, Z.; Shao, Q.; Pan, D.; Wujick, E.; Guo, J.; Xie, X.; Xie, X.; Guo, Z. Crosslinkednorbornene copolymer anion exchange membrane for fuel cells. J. Membr. Sci. 2018, 556, 118-125. [CrossRef]

54. Guo, X.; Ge, S.; Wang, J.; Zhang, X.; Zhang, T.; Lin, J.; Zhao, C.X.; Wang, B.; Zhu, G.; Guo, Z. Waterborne acrylic resin modified with glycidyl methacrylate (GMA): Formula optimization and property analysis. Polymer 2018, 143, 155-163. [CrossRef]

55. Lu, M.; Huang, S.; Chen, S.; Ju, Q.; Xiao, M.; Peng, X.; Wang, S.; Meng, Y. Transparent and super-gas-barrier PET film with surface coated by a polyelectrolyte and Borax. Polym. J. 2018, 50, 239-250. [CrossRef]

56. Cui, Y.; Kundalwal, S.I.; Kumar, S. Gas barrier performance of graphene/polymer nanocomposites. Carbon 2016, 98, 313-333. [CrossRef]

57. Kim, S.J.; Song, E.; Jo, K.; Yun, T.; Moon, M.-W.; Lee, K.-R. Composite oxygen-barrier coating on a polypropylene food container. Thin Solid Films 2013, 540, 112-117. [CrossRef] 